\title{
Gender Gap among the BPL Households of Tea Gardens and Villages of Dibrugarh District of Assam
}

\author{
Bidisha Mahanta \\ Assistant Professor, Department of Economics, DoomDooma College. \\ Email: sonmoni_mahanta@yahoo.co.in
}

\begin{abstract}
The present paper aims to analyse the status of gender gap among the BPL households of Panitola Block of Dibrugarh District of Assam. The target households are divided into two groups --village and tea gardens and then compared the gender gap status of the two groups using indicators like education, employment, political participation, household decision making and attitude towards unequal gender role. The study reveals that gender gap exists in areas like education and employment. However gaps in educational attainment and employment are more in village households as compared to tea garden households. In household decision making also gender gap exists and it is more prominent in tea garden. However in regard of political empowerment, not a single person of the study area is a member of even the Gaon Panchayat. So their political empowerment is analyzed through their participation in political process merely by casting vote. All the respondents from the study area show negative attitude towards unequal gender role and reported that they do not support wife beating and treat both male and female child equally. From the study we have found that tea garden women are more empowered than village women as less gender gap prevails in tea garden as compared to village.
\end{abstract}

Keywords: BPL, Village, tea garden, Gender gap, Gender disparity

\section{Introduction:}

The past few decades witnessed a steadily increasing awareness of the need to empower women and achieving gender equality through measures to increase social, economic and political equity, and broader access to fundamental human rights, improvements in nutrition, basic health and education. The concept of gender equality has been gaining importance as the subordinate status of women in relation to men has been seen in almost every facets of life. Gender equality refers to that stage of human development at which the rights, responsibilities and opportunities of individuals will not be determined by the fact of being born male or female, in other words, a stage when both men and women realize their full potential and become a partner in every sphere of their lives. Realizing the extent of gender inequality throughout the world, the United Nations Development Fund for Women (UNIFEM) was established as a separate fund within the United Nations Development Program (UNDP) in 1984. At that time, the General Assembly instructed it to ensure women's involvement with mainstream activities. The Platform of Action resulting from the 1995 Beijing World Conference on Women expanded this concept, calling it "gender mainstreaming"-i.e. the application of gender perspectives to all legal and social norms and standards, to all policy development, research, planning, advocacy, development, implementation and monitoring - as a mandate for all member states. In this way, the gender factor is no longer to be only a supplement to development but central to the practice of development. As a result of

(C) AesthetixMS 2020. This Open Access article is published under a Creative Commons Attribution Non-Commercial 4.0 International License (http://creativecommons.org/licenses/by-nc/4.0/), which permits non-commercial re-use, distribution, and reproduction in any medium, provided the original work is properly cited. For citation use the DOI. For commercial re-use, please contact editor@rupkatha.com. 
the Beijing conference- and the many years of work leading up to it-more than 100 countries announced new initiatives to improve the status of women. In 2000, the follow-up Beijing +5 conference further strengthened the application of the mainstreaming concept, and used it to highlight the need for more progress in reaching equality worldwide. Similarly in human development font, it is gradually realized that if the women, who constitute almost half of the population, have remained as passive, human development in its real sense cannot be possible. Therefore in 1995 Human Development Report, the main emphasis was on gender equality. The first global gender indices were launched in the 1995 HDR - the Gender related Development Index (GDI) and the Gender Empowerment Measure (GEM) - just before the Fourth World Conference on Women, held in Beijing. The GDI considered inequalities by gender in the HDI dimensions. It measures the inequalities confronted by women in achievement of those which are very essential for overall development of human being. The GEM focused on political participation (measured by women's shares of parliamentary seats), economic participation (shares of high level and professional positions) and power over economic resources (income gaps). The disadvantages facing women and girls are a major source of inequality. Very often, women and girls are discriminated against health, education and the labour market-with negative repercussions for their freedoms. Human Development Report 2010 introduce a new measure of these inequalities built on the same framework as the HDI and the IHDI - to better expose differences in the distribution of achievements between women and men. This is known as Gender Inequality Index (GII)

The Gender Inequality Index shows that:

- Gender inequality varies tremendously across countries-the losses in achievement due to gender inequality (not directly comparable to total inequality losses because different variables are used) range from 17 percent to 85 percent. The Netherlands tops the list of the most gender-equal countries, followed by Denmark, Sweden and Switzerland.

- Countries with unequal distribution of human development also experience high inequality between women and men, and countries with high gender inequality also experience unequal distribution of human development. Among the countries doing very badly on both fronts are Central African Republic, Haiti and Mozambique.

The Gender Inequality Index (GII), estimated for 138 countries, reveals gender disparities in reproductive health, empowerment and labour market participation. The losses in these achievements due to gender inequality, as expressed by the GII, range from 17 percent to 85 percent, with larger losses concentrated in the Arab States and South Asia. (HDR 2010).

Along with these measures of measuring gender inequalities the Global Gender Gap Index, introduced by the World Economic Forum in 2006, is another measure for capturing the magnitude and scope of gender-based inequalities and tracking their progress. The Index benchmarks gender gaps on economic, political, education- and health based criteria, and provide country rankings that allow for effective comparisons across regions and income groups, and over time. Gender gap is measured through the construction of Gender Gap Index. It examines the gap between men and women in four fundamental categories: (1) Economic participation and opportunity is captured through three concepts: the participation gap, remuneration gap and advancement gap. While participation gap is captured through the difference in the rates of labour force participation, the remuneration gap is captured by the estimated ratio of female-tomale earned income and a qualitative variable based on Executive Opinion Survey by the World Economic Forum. The advancement gap is captured through the ratio of women to men among 
legislators, senior officials and managers, and the ratio of women to men among technical and professional workers. (2) Educational attainment is captured through the ratios of women to men in primary, secondary and tertiary level of education; and a longer term view of the country's ability to educate women and men in equal numbers is captured through the ratio of the female to the male literacy rate. (3) Political empowerment measures the gap between men and women in political decision-making at the highest levels. The indicators used are the ratio of women to men in ministerial level and parliamentary level positions including executive positions like Prime Minister and President (4) Health and survival gap between women and men is measured through life expectancy. This measure provides an estimate of the number of years that women and men can expect to live in good health, by taking into account the years lost to violence, disease, malnutrition or other relevant factors. The second measure in this respect is in terms of sex ratio at birth. This variable aims specifically to capture the phenomenon of "missing women" prevalent in many countries with strong preference for son.

\section{Gender gap at Global Level:}

According to the reports of WEF, the large populous nations such as India, Pakistan, Turkey and Egypt hold some of the lowest ranks in respect of gender gap. The study puts Sweden, Norway, Denmark and Iceland on the top of the list. These countries are characterized by strong liberal society, with an impressive record of openness and transparency in government and comprehensive safety net which provides security to vulnerable group of the population. As a result women of this part of the world enjoy greater access to education, work opportunity and a higher standard of living. Although no country has yet succeeded in eliminating the gap, it is narrowed in case of Nordic countries. The 2013report throws a valuable snapshot of the current performance of 136 countries. On average, over 96 per cent of the gap on health outcomes, 93 per cent on educational attainment, 60 per cent on economic participation and 21 per cent on political empowerment has been closed. The three highest ranking countries- Iceland, Finland and Norway have been able to close their gender gaps significantly (over 80 per cent), while the lowest ranking country, Yemen, has closed only around 46 per cent of its gender gap. India's position is 101 among 136 countries in global gender gap report. In 2014, 25 countries have fully closed the gap in Educational Attainment (same as 2013). Angola, Ethiopia, Yemen, Guinea and Chad hold the last five spots on this sub index, with Yemen and Chad having closed less than 7o\% of their education gender gap. Thirty-five countries (two more than 2013) have fully closed the gap in Health and Survival. Vietnam, Albania, China, India and Armenia are the lowest-ranking countries and no country currently has a gap bigger than $90 \%$ on this sub index. On the Economic Participation and Opportunity sub index, 14 countries have closed more than $80 \%$ of gap. Burundi, Norway, Malawi, the United States and the Bahamas occupy the top five spots. On this sub index, Seventeen countries have closed less than 50\% of the economic participation and opportunity gap. On political empowerment, only Iceland and Finland have closed more than $60 \%$ of the gender gap. Thirty-seven countries have closed less than $10 \%$ of the political empowerment gender gap. So far, no countries in the world have been able to eliminating gender inequality. The 2014 report throws a valuable snapshot of the current performance of 142 countries. It shows that the 142 countries covered in the Report have closed almost 96\% of the gap in health outcomes between women and men and almost $94 \%$ of the gap in Educational Attainment. However, the gap between women and men on economic participation and political empowerment remains wide: only $60 \%$ of the economic outcomes gap and only $21 \%$ of the political outcomes gap has been closed.[ WEF GGGR-2014] India showed a steady improvement 
from 2010. However its overall score has slightly decreased in 2014 with its rank 114 among 142 countries. In Assam gender gap is mostly seen in literacy rate, Infant mortality rate, Estimated earned income, work participation rate. According to 2011 census, 11.54 per cent gender gap is seen in literacy rate as a whole. This gap of literacy is found to be more pronounced in rural areas than in urban areas. Gender gap in literacy is 12.3 per cent in rural areas and 6.9 per cent in urban areas. Almost 43 percent gender gap is seen in work participation rate according to 2011 census. The infant mortality rate of the state is 58 with male IMR 56 and female IMR 60 thus indicating a gap of 3 in 2010. [Govt of Assam, 2011]. GDI value of Assam is 0.585 in 2006. However in Dibrugarh District gender gap in literacy is 13.83 which is slightly higher than the state. The rural urban differences are seen in respect of achievements of literacy rate. For rural area gender gap in more acute and is of 15.55 per cent as against 5.95 per cent in urban areas. [Census 2011] IMR is 55 in Dibrugarh which is lower than the state. Gender gap in work participation is almost 26 percent in case of Dibrugarh. The GDI value for Dibrugarh is 0.642.[Govt. of Assam, 2003]

\section{Review of Literature:}

A good number of literatures are available on gender issues. For instance, Wallace and March (1991) explained the effects of global issues on women lives and explored the conceptual basis of gender awareness planning and implementation of development project. Moser (1993) focused on the interrelationship between gender and development, the formulation of gender policy and the implementation of gender planning and practices. Anand and Sen (1995) in their work tried to develop measure of gender inequality. Nussbaum (2001) held the view that international political and economic thought must be sensitive to gender difference as a problem of justice, and that feminist thought must begin to focus on the problems of women in the third world. Hicks (2002) critically examined Sen's view on gender inequality and capability approach and its applicability in religious ethics. The edited volume of Mahanta (2002) sought to explain the question of women's access to or deprivation of basic human rights as the right to health, education and work, legal rights, rights of working women and issues like domestic violence, all the while keeping the peculiar socio-cultural situation of the North East India in mind. Another paper aimed to analyze the debate in the 1990 os between two main approaches on gender economics, the Capabilities-entitlements and the New Poverty Agenda approaches (M Ufuk Turan, 2003.). This paper intended to determine the main differences on those topics between those approaches. In addition to that, the paper discussed the refined definitions of those approaches on various topics of gender economics.

Oriel Sullivan (2004) in his article examined the changing gender relations between heterosexual couples in the domestic spheres. World Economic Forum's reports on gender gap assessed the status accorded to women in a broad range of countries. The first report on global gender gap which was published in 2005 attempted to measure gender inequality for 58 countries in which India ranked at 53.Since then ten reports have been published and the coverage of countries has increased from 58 in 2005 to 142 in 2014 Social Watch (2005) also constructed Gender Equality Index (GEI). The GEI is conceptually different as it was designed to measure the degree of gender equity in different countries without any connection to the general situation of the population. Global Monitoring Report (2007) reviewed the evidence on the relationship between gender equality, poverty reduction and growth. There was also compelling evidence that gender equality and women's empowerment were channels to attaining universal primary education. Amie Gaye and others (2010) reviewed ways to measure and monitor gender inequality. They provided a critique of existing measures including the first global gender indices introduced in the HDR 
(1995), i.e., the Gender-related Development Index and the Gender Empowerment Measure. They also introduced a new index that was included in the Human Development Report in 2010.

\section{Objective:}

The present paper is an attempt to analyze the status of gender inequality in Dibrugarh District (Panitola Development Block) of Assam using various indicators based on data from primary sources.

\section{Area of Study:}

Area of study is the Panitola Development Block which is one of the seven development blocks of Dibrugarh district of Assam.

\section{Data and Methodology:}

The extent of gender gap in Panitola development block has been studied in four fundamental areas like economic participation and opportunity, education, health and political participation using the indicators like literacy rate, work participation rate (WPR), women's political participation, Household decision making and attitude towards unequal gender role using primary data. Gender differentials in these areas are calculated and analyzed after collecting the data. For this a sample of 70 BPL households were collected of which 35 households were from rural areas and remaining 35 households were from tea garden area.

\section{Analysis:}

Let us examine the status of gender inequality in the study area using indicators like literacy rate, work participation rate (WPR), women's political participation, Household decision making and attitude towards unequal gender role.

\section{Gender gap in Literacy Rate:}

Literacy is the first step to formal education. It is seen that in the study area the gender gap in literacy rate exists which indicates that male are more literate than female population of the area. The following table shows the gender gap in literacy rate.

Table 1: Gender gap in Literacy Rate (In percent), 2014

\begin{tabular}{|l|c|c|c|}
\hline $\begin{array}{l}\text { Panitola Development } \\
\text { Block }\end{array}$ & Male & Female & Gender gap \\
\hline Tea garden & 22.86 & 14.29 & 8.57 \\
\hline Rural & 22.86 & 11.43 & 11.43 \\
\hline
\end{tabular}

Source: Field Survey 
From the table it is clear that the gender gap in literacy rate is more in rural areas than in tea garden. However the gender gap in literacy rate is lower than national average (16.68\%) and state average (11.54\%). [Census, 2011]. However in absolute term the performances are poor in both the sexes irrespective of the area.

\section{Gender differentials in Employment level:}

Female work participation rate is one of the indicators of employment status of women. The gender differential in employment level is analyzed taking the difference in male and female work participation rate of the area. From the table it is seen that gender gap in work participation rate is higher in rural areas as compared to tea garden areas implying that the women of tea garden are relatively more employed than those of rural areas.. If we analyze the status of employment in both the areas we will find that the tea garden is doing well in this field. The employment for kind is less in tea garden (male) as compared to BPL Households of rural areas. Cash employment is more in tea garden. However in Assam the gender gap in employment is far less (12.4 per cent) in rural areas and in national level it is 21.9 per cent.

Table2: Gender Gap in work participation Rate, 2014 (in percent)

\begin{tabular}{|l|c|c|c|c|c|c|c|}
\hline \multirow{2}{*}{$\begin{array}{l}\text { Panitola } \\
\text { Development Block }\end{array}$} & \multicolumn{3}{|c|}{ Male } & \multicolumn{3}{c|}{ Female } & $\begin{array}{c}\text { Gender } \\
\text { Gap }\end{array}$ \\
\cline { 2 - 9 } & cash & Kind & unemployed & cash & kind & unemployed & \\
\hline Tea garden & 62.86 & 25.71 & 11.43 & 28.57 & 8.57 & 62.86 & 51.43 \\
\hline Rural & 45.71 & 28.57 & 25.72 & 2.86 & -- & 97.14 & 71.42 \\
\hline
\end{tabular}

Source: Field Survey

\section{Gender Disparity in Political Participation:}

Women's political participation is another input to their empowerment. It is one of the important factors that contribute to their wellbeing. Empowered women have political freedom which in turn translates into their decision making capacity both at the community and national level. Women's representation in political field even in its most modest form of local government has the ability to transform and reinterpret the practice of politics (Workshop report 2003). It helps to create better village communities based on harmony and cooperation achieved through gender balance and justice. However in case of India and even in the north east, the strong family based structure of Indian politics makes it difficult for women to assert independent political choices, as distinct from the male headed families. Therefore judging women's political agency on the basis of their representation in political bodies is hazardous, women standing proxy for men are quite common in India [ Assam human development Report 2003].

However the representation in local bodies does not always indicate that women are politically empowered as in most cases they act as proxies of their male counterparts. Here it is found that the entire respondent cast vote but not on their own will but with the influence of their spouse and other members of the family. And nobody respective of sexes represent political bodies. 


\section{Gender disparity in House hold decision making:}

It is another indicator of women empowerment and thus can be a source of gender inequality: Empowered women can take major household decisions by their own. However it is found that in the study area in most of the cases the major household decisions are taken by both respondent and spouse. From the table it is found that in tea garden area their exist gender gap of 8.57 percent in household decision making however in rural areas, women's decision making is more than that of men, But this cannot be interpreted as women are superior in this field than their counterparts as all those households of rural areas where wife alone make decision are female headed households.

Table 3: Gender gap in household Decision Making 2014 (in percent)

\begin{tabular}{|l|c|c|c|c|}
\hline Area & \multicolumn{2}{|c|}{ Major Household Decisions taken by } & \multirow{2}{*}{$\begin{array}{c}\text { Gender } \\
\text { Gap }\end{array}$} \\
\cline { 1 - 2 } $\begin{array}{l}\text { Panitola Development } \\
\text { Block }\end{array}$ & Husband & Wife & Both & \\
\hline Tea Garden & 17.14 & 8.57 & 74.29 & 8.57 \\
\hline Rural & 11.42 & 17.14 & 71.42 & $(-)_{5.72}$ \\
\hline
\end{tabular}

Source: field survey

\section{Attitude towards Unequal Gender Role:}

Attitude towards unequal gender role in one of the important indicator of women empowerment. A society with high degree of gender inequality exhibits a positive attitude towards unequal gender role. Data of NSSO (2004-05) shows that in India 54.1 per cent women accept unequal gender role. However here in the Panitola block, the entire respondents are agreed that they treat equally both male and female child of their family and they never support wife beating.

\section{Findings:}

The major findings are as follows

1. Gender gap exists in literacy Rate. But this is less than national and state average. In absolute term the literacy rate of both male and female is very low. However tea garden area shows an improvement over rural area. But the good sign is that all the families send their children to school and all the school going age children are literate.

2. Gender gap exists in work participation rate too. Here the gender gap is more in rural areas as compared to tea garden areas. Relative to rural area, women employment is more in the tea gardens. Employment for cash is more in tea garden and employment for kind is more in rural areas.

3. Gender gap exists in household decision making. Generally decisions are taken by both husband and wife. But in some cases husband alone take decisions and in the female headed households decisions are taken by the women. 
4. All the respondents cast vote but not on their own. They are influenced by their spouse and other family members.

5. All the respondents said that they show no discriminations against the girl child.

\section{Conclusion}

Although various efforts have been made to empower women and to eliminate gender gap, they are not to that extent successful in achieving the goal. In national level and in the state level gender gap exists and the condition is more alarming among the below poverty line people. Here gap exists and in absolute term also the status of human development indicators like literacy rate, employment level etc are not satisfactory. Giving property right, access to employment or educational opportunity on the part of the government will not change the picture. A revolutionary change in the social and cultural values and behavioral pattern is necessary to foster the process of achieving gender equality. When women feel that they have the capability of operate the society at the same term as men then achieving gender equality will not remain as a distant dream.

\section{References}

Anand, S. and A. Sen (1995). Gender inequality in Human Development: Theories and Measurement. In Fukuda Parr and A.K. Shiv Kumar (Eds.) Readings in Human Development, OUP, New Delhi

Census Data 2011, GOI.

Gaye Amie, J. Klugman, M. Kovacevic, S. Twigg, and E. Zambrano. (2010). Measuring Key Disparities in Human Development: The Gender Inequality Index. Paper provided by Human Development Report Office (HDRO), United Nations Development Programme (UNDP) in its series Human Development Research Papers (2009 to present) with number HDRP-2010-46

Global Monitoring Report (2007). Promoting Gender Equality and Women's Empowerment

Govt. of Assam (2003). Assam human development report. Planning and Development Department, Dispur, Assam.

Govt. of Assam (2003). Women: Striving in an unequal World. Assam Human Development Report

G.O.I.(2008). Kurukshetra; A Journal on Rural Development, 56(3), January, Ministry of Rural Development.

G.O.I.(2002). National human development report, 2001, Planning Commission, New Delhi.

Hicks, D.A. (2002). Gender discrimination and capability: Insights from Amartya Sen. The Journal of Religious Ethics, 30(1).

I.B.R.D.(2007). Global monitoring report. Millennium development goals: confronting the challenges of gender equality and fragile states. Retrieved from $<\mathrm{http}: / /$ siteresources.worldbank.org/ INTGLOMONREP2007/Resources/3413191-1176390231604/1264-FINAL-LO-RES.pdf $>$. Visited on $7^{\text {th }}$ February 2011 at 11.37a.m.

Mahanta, A. (Ed.) (2002). Human Rights and Women of North East India, Centre for Women's Studies, Dibrugarh University, Dibrugarh

Mathew, G. (2003). Keynote address in the workshop on “A Decade of Women's Empowerment through Local Governance” organized jointly by Institute of Social Sciences and South Asia Partnership, Canada sponsored by International Development Research Centre. 
9 | UNDP (1990-2010). Human Development Reports, OUP, Oxford.

Moser, Caroline O. (1993). Gender Planning and Development: Theory Practice and Training, available from Women, Ink. 1

Nussbaum, M. (2001). Women and Development, Retrieved from http://www.pnayak.webs.com. Visited on $13^{\text {th }}$ September 2010 at 8.30 p.m

NSSO (III ROUND -2004-2005)

Social Watch (2005).Social watch report: Roars and Whispers. Gender and Poverty: Promises Vs Action,2005.

Sullivan Oriel (2004). Changing Gender Practices within the Household: A Theoretical Perspective. Retrieved from http://www.pnayak.webs.com. Visited on $13^{\text {th }}$ September 2010 at 9.30 p.m

Turan M. Ufuk (2003). The Gender Economics: The Debate over Gender Inequality and“HUMAN” Poverty during the 1990s. Retrieved from https://dergipark.org.tr/tr/pub/eab/issue/39834/472277.

UNDP (1990-2010). Human Development Reports, OUP, Oxford.

Wallace T and C. March (1991) (Eds.). Changing Perception: Writing on Gender and Development, Oxfam Press, Oxford.

World Economic Forum (2005-2010). Global Gender Gap Reports. 